\title{
Promoting Students Critical Thinking through Massive Open Online Course
}

\author{
$1^{\text {st }}$ Saefurrohman, $2^{\text {nd }}$ Lutfi istikharoh \\ saefurrohman@ump.ac.id ${ }^{1}$, lutfiistikaroh@ump.ac.id ${ }^{2}$ \\ Universitas Muhammadiyah Purwokerto, Jl KH. Ahmad Dahlan PO BOX 2020, Indonesia ${ }^{1,2}$
}

\begin{abstract}
The process of transmitting knowledge and educational paradigms are evolving as a result of advancements in information technology. Various remote education systems, often known as MOOCs (Massive Open Online Courses), have evolved in tandem with the advancement of the times. MOOC is an alternative to formal education in today's environment, with a learning paradigm and certifications that are similar to conventional education that can promote the students critical thinking. Certain strategies promoted during MOOCs may improve learners' critical thinking abilities. Learners were apparently encouraged to participate in questioning activities, encourage interaction, and develop a sense of critical thinking.
\end{abstract}

Keywords: Technology, MOOC, Critical Thinking.

\section{Introduction}

The function of the education community cannot be isolated from developments in the field of educational technology, which are always changing. The rapid development of information technology, which may produce software and hardware, is one of the aspects that supports the achievement of educational goals or concepts. Currently, the educational paradigm has evolved to include information technology as a medium for knowledge acquisition, both in the classroom and through academics and research [1].

There is currently no official record establishing the official launch of e-Learning in Indonesia. Efforts to establish e-Learning have been proposed since early 1995 , according to numerous interviews, but e-Learning was forced to be discontinued until the early 2000 s due to the economic and political crisis that hit Indonesia in mid-1997 [2]

Various educational institutions conduct large E-Learning learning during the Covid 19 Pandemic, beginning with the use of LMS (Learning management systems, video conferencing, social media groups, etc.) [3]. Massive Open Online Courses (MOOCs) are a type of E-Learning that has been developed but is yet rarely used (MOOC) [4]. MOOCs are a type of online training that is mass-produced with the goal of improving participant performance in specific subjects. The participation of users in the forums provided on the service site is one of the most significant features of MOOC-based learning[5].

Participants in a MOOC can select from a selection of classes based on their subject of interest. MOOC classes include a wide range of topics, including education, economics, computers, and biology. Participants will receive video lectures and important materials on the area after enrolling in the class. Furthermore, most MOOCs include projects that can be completed to have a better knowledge of the topic being taught. Because flexibility is an 
important feature of MOOCs, participants are given the option of when they can access course materials and assignments

\section{Research Methods}

A review of the literature was utilized as the methodology of investigation in this study. As a research study, a literature review, also known as a literature study, is a kind of inquiry that contains concepts that are connected to the topics under examination [6]. The ideas and assumptions given in this section are evaluated in light of the current literature, which is comprised of articles from a range of scientific journals and other publications.[7] After everything has been said and done, the ultimate goal of a literature review is to create concepts or ideas that will serve as the basis for future research endeavors.

Following the gathering of all of the information, the next step is to evaluate it in order to reach a conclusion on the subject matter under consideration and content analysis techniques throughout the data analysis process was used. [8]

\section{Results and Discussion}

\subsection{MOOC for promoting students' critical thinking}

The massive open online course concept (MOOC) is very new and provides free internet classes for large-scale student registrations. Although most students don't get the college credit, MOOCs draw millions of students to take various courses each year [9]. The new environment of the MOOC leaves instructors with thousands of enrollments to educate, some without knowing how to teach in the new online setting. Many see teaching MOOCs as experimental, and educators thus employ a range of methods to promote engagement and learning of students

Massive Open Online Course (MOOC) is a kind of online learning that allows for the scaling of a huge and diverse group of learners spread over many and distant places [5]. This MOOC-style learning activity is often conducted online, through a website that is accessible over the internet. MOOC is already proved increasing the students' critical thinking

Critical thinking is more than simply the act of thinking; it has also become an essential talent to have [10]. Critical thinking was rated higher than creativity or information and technology expertise as an essential talent greatly needed in future job experience. Considering all of the critical thinking definitions presented above, as well as its essential advantages in the workplace, it is reassuring to know that the feeling of critical thinking is linked with cognitive ability and the process of higher level thinking. Before entering the professional world, one must first get experience in critical thinking in school.

Students who participate in MOOCs may feel more confident in their ability in increasing their critical thinking skill. Most of the theoretical arguments in favor of the asynchronous interactions accessible in MOOCs for the purpose of encouraging critical thinking have focused on the students' chances to actively absorb material, ponder, and explore issues before replying to them [11]. Recapitulating all of the reasons, it can be claimed that MOOC is more popular, conducive, and compatible than conventional pedagogical approaches in terms of improving students' critical thinking in contemporary educational environment than some others.

\subsection{Some MOOC Activities for asingincrecritical thinking}


There are some activities throgh MOOC that can improve the students critical thinking . The activities are

1. Discussion Forum

Discussion forums is utilized in a variety of ways by teachers to facilitate and promote student engagement and social learning [12]. While techniques of forcing students to post are likely to boost student participation on forums, they do not encourage reading, commenting, or participating in meaningful discussion. Furthermore, teachers tried to encourage student involvement on forums through modeling, in which an instructor would make a forum post, wait for a response, and then engage a student or a few students in a conversation.

Another technique for enhancing social learning in forums was the practice of student modeling, which required students to complete assignments through a dedicated forum [13]. This may not work for every kind of class - a quantitative course with assignments that clearly yields right or incorrect responses would be giving away the correct answer after a few postings.

2. Students peer assessment

Student peers assessed each other's work anonymously, using a criteria given in the course to determine how well they do on their assignments [14]. A point system is used to assess whether or not the work fulfilled specific requirements, and students are asked to award points on a scale. A student was required to provide a numerical evaluation, as well as a justification for the grade they received. Using incentives to encourage student engagement during peer evaluations isanother method of ensuring student interaction. In order to pass the course, students areneeded to participate in peer evaluation activities [15].

Students are asked to develop future research ideas based on course contents as part of an individual class project, which has been assigned by the instructors. In addition to grading the projects, peers are permitted to provide comments and had the option of sending the project to the instructors for evaluation. The teachers then evaluatedthe most popular projects and select the top three students to receive awards.

3.. Social activities

When students feel more connected or socially engaged with an online course, their learning improves. A variety of techniques were employed in the MOOCs examined to make students feel like they were part of a class or more aware of their fellow students [4]. These exercises, if effective, may have helped decrease the psychological distance pupils felt from one another. Other social learning techniques, such as group work, may certainly have enhanced a student's sense of connection to other students, but this category to include activities that appeared to have no other function than enhancing social presence [16]. With the exception of a few techniques, it was impossible to tell whether one was more or less likely to enhance a sense of social presence than another.

\section{Conclusion}

In conclusion, including critical thinking into MOOCs covers all the bases of contemporary education. All of the critical thinking's essentiality and positivity are becoming desirable skills in the globalized age. Teachers emphasize the ideals, concepts, and behaviors associated with critical thinking as the goal of today's higher education environment. Additionally, the presence of technology, such as MOOCs, is seen as an unavoidable element influencing many dimensions of teaching-learning systems. Whether instructors like it or not, they must get acquainted with technology. MOOC has been proven to be an effective tool for fostering students' critical thinking. 


\section{References}

[1] M. M. Yunus and A. Suliman, "Information \& Communication Technology (ICT) tools in teaching and learning literature component in Malaysian secondary schools," Asian Soc. Sci., 2014, doi: 10.5539/ass.v10n7p136.

[2] Z. Zaharah and G. I. Kirilova, "Impact of Corona Virus Outbreak Towards Teaching and Learning Activities in Indonesia," SALAM J. Sos. dan Budaya Syar-i, 2020, doi: 10.15408/sjsbs.v7i3.15104.

[3] J. S. Mtebe, "Learning Management System success: Increasing Learning Management System usage in higher education in sub-Saharan Africa," Int. J. Educ. Dev. Using Inf. Commun. Technol., 2015.

[4] J. G. Mazoue, "The MOOC Model : Challenging Traditional Education," Educ. Rev., 2013.

[5] J.-C. Pomerol, Y. Epelboin, C. Thoury, J.-C. Pomerol, Y. Epelboin, and C. Thoury, "What is a MOOC?," in MOOCs, 2015.

[6] Dbrc, "Design-Based Research: An Emerging Paradigm for Educational Inquiry," Educ. Res., vol. 32, no. 1, pp. 5-8, 2003, doi: 10.3102/0013189X032001005.

[7] E. Ingleby, "Research methods in education," Prof. Dev. Educ., 2012, doi: 10.1080/19415257.2011.643130.

[8] L. Cohen, L. Manion, and K. Morrison, Research Methods in Education, vol. 55, no. 4. Routledge, 2007.

[9] C. Tømte, A. Fevolden, and D. S. Olsen, "To MOOC or not to MOOC?," 2014.

[10] T. Anderson, "Teaching in an Online Learning Context," Theory Pract. online Learn., 2008.

[11] S. Robla, J. R. Llata, C. Torre-Ferrero, E. G. Sarabia, and J. Perez-Oria, "OPEN COURSE WARE AND MASSIVE OPEN ONLINE COURSE EXPERIENCE AT THE UNIVERSITY OF CANTABRIA," 2014.

[12] J. L. Bishop and M. A. Verleger, "The flipped classroom: A survey of the research," 2013, doi: 10.18260/1-2--22585.

[13] G. Tularam and P. Machisella, "Traditional vs Non-Traditional Teaching and Learning Strategies -- The Case of E-Learning!.," Int. J. Math. Teach. Learn., 2018.

[14] Muhaemin, "Massive open online course: Opportunities and challenges in state islamic higher education in Indonesia," Asian EFL J., 2019.

[15] A. H. Lubis, S. Z. S. Idrus, and S. A. Rashid, "The exposure of MOOC usage in Indonesia," Int. J. Sci. Technol. Res., 2020.

[16] A. Nurhudatiana, A. Anggraeni, and S. Putra, "An exploratory study of MOOC adoption in Indonesia," 2019, doi: 10.1145/3337682.3337690. 